\title{
Auditory ossicles: a potential biomarker for maternal and infant health in utero
}

Tamara Leskovar ${ }^{\mathrm{a} *}$, Julia Beaumont ${ }^{\mathrm{b}}$, Nidia Lisićc ${ }^{\mathrm{c}}$ and Suzanne McGalliard ${ }^{\mathrm{d}}$

${ }^{a}$ Department of Archaeology, Faculty of Arts, University of Ljubljana, Ljubljana, Slovenia; https://orcid.org/0000-0002-4585-4726

${ }^{\mathrm{b}} \mathrm{School}$ of Archaeological and Forensic Sciences, University of Bradford, Bradford, UK; https://orcid.org/0000-0002-7166-5857

${ }^{c}$ Museum of London Archaeology, London, UK

${ }^{\mathrm{d}}$ MOLA Headland Infrastructure, 13 Jane Street, Edinburgh, UK

Faculty of Arts, Department of Archaeology, Zavetiška 5, 1000 Ljubljana, Slovenia, Tamara.Leskovar@ff.uni-lj.si *

Wordcount: 4962 


\section{Auditory ossicles: a potential biomarker for maternal and infant health in utero}

\section{Abstract}

Background: carbon $\left(\delta^{13} \mathrm{C}\right)$ and nitrogen $\left(\delta^{15} \mathrm{~N}\right)$ isotope ratios of collagen from teeth and bone are used to study human nutrition and health. As bones are constantly remodelling throughout life, isotopic values of bone collagen represent an average of several years. In contrast, human teeth do not remodel, and their primary dentine contains only the isotopic data from the time of formation. In contrast to all other bones, human auditory ossicles also appear not to remodel. As they develop in utero and finish formation in the first two years of life, their collagen should also represent isotopic values of these two relatively short periods. Aim: By comparing $\delta^{13} \mathrm{C}$ and $\delta^{15} \mathrm{~N}$ data from ossicles and incremental dentine our study aims to investigate how two developmental periods of the ossicles, in-utero and first two years of life, reflect in collagen obtained from the ossicles.

Subject and methods: Ossicle and tooth samples of 12 individuals aged $0.5 \pm 0.4$ years to 13 \pm 1 years from the $19^{\text {th }}$ century St. Peter`s burial ground in Blackburn were collected and processed to obtain bulk bone and incremental dentine collagen which was measured for $\delta^{13} \mathrm{C}$ and $\delta^{15} \mathrm{~N}$.

Results: Averaged $\delta^{13} \mathrm{C}$ and $\delta^{15} \mathrm{~N}$ of ossicles are lower when compared to every age group except after 3 years of age. Average offset between ossicles and dentine of different groups ranges from 0.4 to $0.9 \%$ for $\delta^{13} \mathrm{C}$ and from 0.3 to $0.9 \%$ for $\delta^{15} \mathrm{~N}$, with highest counterbalance at birth and after first 5 months after birth.

Conclusions: There appears to be a systematic offset between the dentine and ossicle data. It seems that the second phase of development does not influence the isotopic values of collagen significantly and the data we are obtaining from ossicles represents the in-utero period.

Keywords: isotope ratios, auditory ossicles, incremental dentine, in-utero biomarker 


\section{Introduction}

Carbon and nitrogen isotope ratios of various human tissues are extensively used to study human nutrition and health through time and space (Reitsema, 2013; Schoeninger, 2011). Due to its robustness and relatively long survivability in the burial environment (Collins \& Galley, 1998), collagen from bone and teeth represents a common resource for stable isotope studies of remains originating from archaeological settings (Lee-Thorp, 2008). Furthermore, with their differing formation times, combining results obtained from bone and tooth analysis offers an insight into different periods of an individual life (Hedges et al., 2007; Beaumont et al., 2013a,b). Due to constant remodelling, isotopic values of bone collagen represent an isotopic average of several years, depending on the skeletal element and age, sex and health of the individual (Hedges et al., 2007; Feng \& McDonald, 2011). In contrast, the formation of human teeth is bound to a narrower period of individual life, and has shown to be reliable despite genetic or socioeconomic status (Armour-Chelu \& Andrews, 1996; AlQahtani et al., 2010; Dean \& Scandrett, 1995) and because teeth do not remodel, primary dentine does not change throughout life (Nanci, 2008). Teeth thus act as a record of childhood and/or adolescence, as their primary dentine only contains the isotopic data from the time of formation. Their stable direction and rate of growth combined with incremental sampling provides a high-resolution isotopic record, which allows us to identify short-term variations which can be attributed to a specific period of life (Fuller et al., 2003; Eerkens et al., 2011; Beaumont et al., 2013b; Balasse et al., 2001; Beaumont et al., 2015).

There is one notable exception to the remodelling of bone. The auditory ossicles are known to develop in utero, finish their formation in the first two years of life and do not remodel afterwards (Palumbo et al., 2012; Duboeuf et al., 2015; Hanson \& Anson, 1962; Yokoyama et al., 1999). The ossicles should thus contain the isotopic values of an individual`s early life. However, as there are no previous studies on the isotopes obtained from human auditory ossicles, it is unclear what period of life they actually reflect. Acknowledging possible issues 
due to "osteological paradox" (DeWitte \& Stojanowski, 2015; Wood et al., 1992) and the apparent offset between co-forming bone collagen and dentine identified in recent studies (Beaumont et al., 2013b; Burt, 2013, 2015; King et al., 2017), but with lack of any data on isotope values obtained from the ossicles, we hypothesise that the prenatal portion of dentine and auditory ossicles should have similar isotope ratios which reflect the in utero experience and maternal diet and physiology. To investigate this hypothesized correlation, in this preliminary study we compare $\delta^{13} \mathrm{C}$ and $\delta^{15} \mathrm{~N}$ values from ossicles and dentine increments formed in utero and in the first two years of life.

\section{St Peter's church and Burial Ground, Blackburn}

During the archaeological excavation at St Peter's burial ground in 2015, 1959 individuals were excavated, with 1254 of these classed as sub-adults. This large number of children, carefully excavated and assessed, gave an opportunity to investigate the health of sub-adults affected by the changes brought about by the Industrial Revolution in a post-medieval town in northern England by analysing the isotope ratios recorded in their bones, teeth and auditory ossicles.

\section{Site Location}

Headland Archaeology were commissioned by Capita on behalf of Blackburn with Darwen Borough Council to undertake full archaeological excavation of burials and church foundations at St Peter's church and burial ground in Blackburn, Lancashire. The site was located to the south-west of the historical centre and covered an area of approximately 4200 $\mathrm{m}^{2}$ (Figure1). Prior to excavation, the site was an open green space, accessible to the public and surrounded on three sides by roads and an industrial unit. Recumbent memorial stones were present on the surface of the site with the foundations of the demolished church visible as cropmarks in the drier months (Ginnever et al., 2019).

Figure 1: Site location, showing planned road alignment and excavation area. 


\section{Project Background}

The archaeological works were undertaken prior to the construction of the Freckleton Street Link Road, part of Blackburn and Darwen Council's Town Centre Orbital Route Scheme, which cut through the site on a north-west to south-east alignment. A small area to the northeast was also required to create a turning head (Ginnever et al., 2019). A Desk Based Assessment by Edgerton Lea Consultancy (2007) initial archaeological evaluation by Oxford Archaeology North (Rowland, 2013) parish registers and studies of memorial stones were consulted to estimate the number of burials which would be impacted by the development. The excavations of the burials and church foundations took place between June and October of 2015. Full artefactual and osteological analysis was undertaken in 2016 (Ginnever et al., 2019).

\section{Overview of Population}

By the end of the $18^{\text {th }}$ century, industrialisation led to development in technology of cotton mills, which resulted in the population of Blackburn increasing from 5000 people in 1780 to over 20,000 by 1821 . The town became increasingly prosperous with the coming of the mills with a boom in trade for coal merchants, shop owners and engineers. Conversely, the industrialisation of the town also led to crowded and squalid conditions, long working hours, child labour and infant mortality (Beattie, 1992).

The rapid increase in the population and industrialisation led to the founding of the Church Building Commission in 1818, which petitioned parliament for the building of new churches. The 'Million pound' or 'Waterloo' act was passed for the construction of new churches. The act stipulated that the new churches had to provide a certain amount of free seating for the poor as organised religion was predominantly viewed as a way of keeping the populace on the straight and narrow. St Peter's church was one of the first churches to be built from this fund, attended by an Anglican congregation. 
The congregation of St Peter's church was described by Beattie as 'middling Tory employers' (Beattie, 1992, 136), however, the baptism records for 1855 somewhat refute this claim with the majority of parents' occupations associated with the textile industry as well as labourers and timber merchants. Further research of named and un-named remains from the burial ground confirms that the congregation represented a broad spectrum of society, ranging from prosperous mill owners to mill workers (Ginnever et al., 2019).

\section{Teeth}

Human tooth and dentine development and their high potential for isotopic studies have been discussed elsewhere (Fuller et al., 2003; Eerkens et al., 2011; Beaumont et al., 2013b, 2015; Beaumont \& Montgomery, 2016). In short, dentine-forming cells called odontoblasts secrete collagen fibre matrix, which is mineralized by hydroxyapatite. Dentine formation starts before the formation of enamel, in the area closest to the future cusp of a tooth and progresses towards the centre of the tooth. When odontoblasts move from the enamel/dentin or cement/dentin junction towards the pulp chamber, a network of S-shape dental tubules remains throughout the thickness of the dentine, providing space for the circulation of the nutrients (Dean \& Scandrett, 1995; Nanci, 2008).

Deciduous teeth start to form at 30 weeks gestation, with incisors and first molars being fully developed after 30 months \pm 6 months from birth plus 2.5 months in utero (at the age of $2.5 \pm$ 0.25 years) and canines and second molars after 36 months \pm 6 months from birth plus 2 months in utero (at the age of $3.5 \pm 0.25$ years) (AlQahtani et al., 2010). The rate of secretion in permanent teeth is relatively consistent ranging from $1.3-1.5 \mu \mathrm{m}$ per day to $4-6 \mu \mathrm{m}$ per day, depending on the part of the tooth (Dean $\&$ Scandrett, 1995). At a rate of $3-5 \mu \mathrm{m}$ per day, dentine secreted by each odontoblast represents approximately $100-150 \mu \mathrm{m}$ (Beaumont et al., 2013b). 
Based on the predictive rate of formation, developmental stage of the tooth and its size, it is estimated that a $1 \mathrm{~mm}$ dentine section of a deciduous tooth represents $\leq 4.5$ months, and a 1 mm dentine section of a permanent tooth $9-12$ months of individual`s life (Beaumont et al., 2013b, 2015).

\section{Auditory ossicles}

The human middle ear contains three auditory ossicles, malleus, incus and stapes. They form a chain from the tympanic membrane to the fenestra vestibuli and are crucial in sound transmission (Williams et al., 1989). Ossicles develop from the pharyngeal arches and mesenchyme of the auditory capsule (Ars, 1989). Auditory ossicles derive from cartilaginous buds which start to ossify in the $3^{\text {rd }}$ to $4^{\text {th }}$ month of prenatal life and have a complex structure of mineralised collagen. Compared to other bones, the rate of their development and final macroscopic and microscopic features are peculiar. With the condensation of the mesenchyme, ossicles can first be observed in the $36^{\text {th }}$ day in utero and present a cartilaginous structure in the $48^{\text {th }}$ day in utero. The ossification begins with the incus at 14 weeks in utero, followed by malleus at 15-16 weeks and stapes at 18 weeks in utero. The periosteal collar with the endochondral bone inside appears in the $19^{\text {th }}-20^{\text {th }}$ week. The ossification is largely completed by the $32^{\text {nd }}-35^{\text {th }}$ week in utero and ossicles achieve their final shape and dimensions at birth. The exceptions are the trabecular fascicle of malleus and incus and the bone marrow cavities, which are finalised approximately 25 months after birth (Hanson \& Anson, 1962; Whyte et al., 2008; Richard et al., 2017; Lasky \& Williams, 2005). Structurally, ossicles are almost completely formed by compact bone, with scarce Haversian canals and thus relatively few blood vessels. Their inner structure is predominantly constructed from woven-fibered, and only partially from parallel-fibered and lamellar bone (Marotti et al., 1998). An even more intriguing feature they possess is restricted bone remodelling (Chen et al., 2008). Since their main function is transmitting tympanic membrane deformation caused 
by sound waves to the inner ear, once completely developed, auditory ossicles are exposed exclusively to mechanical stereotyped stress. As such, they have to provide structural stability and the process of bone remodelling needs to be avoided. Thus, on the contrary to other skeletal elements, they experience massive programmed osteocyte death (apoptosis) with over $40 \%$ of cells dying within the second year of life. This lack of viable osteocytes restricts any bone remodelling (Marotti et al., 1998; Palumbo et al., 2012). The latter is true even when the ear is subject to inflammation, when osteoclastic activity predominates, leading to irreversible bone erosion and increased porosity, with minimal or no new bone formation (Duboeuf et al., 2015; Dornelles et al., 2007).

Their unique pattern of development and lack of remodelling suggest that the ossicles should possess collagen deposited mainly in utero and, to a lesser extent, in the first two years of life. Our study aims to investigate which of these two periods of development are reflected in the collagen of the ossicles, and to which extent those two periods influence the recorded values. This should be achieved by comparison of ossicle data with the incremental dentine collagen profiles of matched individuals.

\section{Materials and methods}

Bone and tooth samples originated from the $19^{\text {th }}$ century St. Peter`s burial ground in Blackburn. 20 individuals aged $0.5 \pm 0.4$ years to $13 \pm 1$ years were included in the study. The age of individuals was assessed based on osteological analysis provided by Headland Archaeology. For this preliminary study, the focus will be on the 12 individuals with both auditory ossicles and teeth preserved (Table 1). From each individual, we selected the tooth with the earliest onset of formation available and either an incus or malleus was sampled. Even though occasionally present, stapes was avoided due to its extremely small size and thus the possibility of not providing enough collagen for the analysis.

Table 1: Sampled teeth and ossicles from 12 Blackburn individuals. 
All the collected ossicles and teeth were cleaned of any surface debris. To speed up demineralisation, tooth enamel was partially removed using a dental handpiece, leaving the enamel-dentine junction intact. Collagen was prepared following the modified Longin method, omitting filtration (Brown et al., 1988;Beaumont et al., 2018). Samples were demineralised using $0.5 \mathrm{M}$ hydrochloric acid at $4{ }^{\circ} \mathrm{C}$. Acid was replaced every $3-4$ days until the demineralisation was completed. Tooth dentine was sectioned following the second method of Beaumont et al. (sectioning after demineralisation) (2013b). Dentine was cut into 1 mm thick samples, commencing from the coronal dentine horn, and the number of sections for each tooth was documented.

Demineralised ossicles and sectioned dentine were subjected to the same protocol for the isotopic analyses. They were rinsed with de-ionised water until neutral $\mathrm{pH}$ was reached. Neutralised samples were placed into microtubes with $\mathrm{pH} 3$ hydrochloric acid solution and exposed to $70^{\circ} \mathrm{C}$ for 24 hours for collagen to denature. No filtration was performed. When present, remnant debris were removed from the solution after centrifugation. Once clear, solution was frozen and freeze dried. From the samples obtained collagen and laboratory and international standards were weighed $(\sim 0.5 \mathrm{mg})$ into tin capsules and measured in duplicate. Samples were combusted in a Thermo Flash EA 1112 and separated $\mathrm{N}_{2}$ and $\mathrm{CO}_{2}$ introduced to Delta plus XL mass spectrometer via a Conflo III interface. Measured values were normalised according to Paul et al. (2007).

Isotope ratio ( $\delta$ in \%o) is expressed relative to international marine limestone PDB standard for carbon and Ambient Inhalable Reservoir (AIR) for nitrogen with the error of $\pm 0.2 \%$, $1 \mathrm{~s} . \mathrm{d}$.

Based on the tooth developmental stage, age range of tooth formation (AlQahtani et al., 2010) and obtained number of dentine sections, the approximate age span of each dentine section 
was calculated. For the graphical visualisation, the midpoint of the age range for each section was used ( $x$-axis) (see Supplementary material).

As different teeth of individuals of various ages were included, dentin sections were divided into six groups (Table 2) to compare teeth from different individuals at the same age, and to then compare them with values obtained from the ossicles $(\mathrm{O})$.

Table 2: Groups established based on dentine formation time.

\section{Results}

Even though dentine increments and demineralised ossicles formed very small samples, they produced enough collagen to perform the analyses with duplicate measurement and met all the accepted quality criteria (van Klinken 1999; Schoeninger \& DeNiro, 1984). Analytical error based on the standards was $0.2 \%$ or less.

\section{General pattern}

Averaged $\delta^{13} \mathrm{C}$ and $\delta^{15} \mathrm{~N}$ for each group are presented in Table 3. When compared statistically, significant differences were found among groups for $\delta^{13} \mathrm{C}$ and $\delta^{15} \mathrm{~N}$ (ANOVA 13.479, $\mathrm{p}=0.000$ and ANOVA 7.146, $\mathrm{p}=0.000$, respectively). When each dentine group was compared to ossicles (O), all but $\delta^{15} \mathrm{~N}$ of PN group (Student s 1.083, $\mathrm{p}=0.312$ ) and $\delta^{13} \mathrm{C}$ and $\delta^{15} \mathrm{~N}$ of $2 \mathrm{y}$ group (Student ${ }^{\mathrm{s}} 2.062, \mathrm{p}=0.054$ and $0.902, \mathrm{p}=0.380$, respectively) presented significant differences $(\mathrm{p}<0.05)$.

Table 3: Average $\delta^{13} \mathrm{C}$ and $\delta^{15} \mathrm{~N}$ separately for ossicles $(\mathrm{O})$ and dentine groups.

Averaged $\delta^{13} \mathrm{C}$ and $\delta^{15} \mathrm{~N}$ of ossicles are lower when compared to every group except $3+\mathrm{y}$ and thus situated between groups $2 \mathrm{y}$ and $3+\mathrm{y}$ (Table 4). Average offset between ossicles and dentine of different groups ranges from 0.4 to $0.9 \%$ for $\delta^{13} \mathrm{C}$ and from 0.3 to $0.9 \%$ for $\delta^{15} \mathrm{~N}$ (Figure 2), with highest values observed between birth and first 5 months after birth. 
Table 4: Average $\delta^{13} \mathrm{C}$ and $\delta^{15} \mathrm{~N}$ offset between ossicles and dentine.

Figure 2: Comparison of $\delta^{13} \mathrm{C}$ and $\delta^{15} \mathrm{~N}$ of ossicles and dentine.

\section{Individual patterns}

Offsets between $\delta^{13} \mathrm{C}$ and $\delta^{15} \mathrm{~N}$ of the ossicles and dentine formed at different time are presented in Figure 3 and Figure 4, respectively.

$\delta^{13} \mathrm{C}$ and $\delta^{15} \mathrm{~N}$ comparison of ossicles and dentine formed before birth shows higher values for dentine. The only exception is $\delta^{15} \mathrm{~N} \%$ of individual 1615 , with higher values observed in the ossicle. The $\delta^{13} \mathrm{C}$ offset between ossicles and pre-natal dentine ranges between 0.1 and $1 \%$ and the $\delta^{15} \mathrm{~N}$ offset between 0.4 and $0.9 \%$.

$\delta^{13} \mathrm{C}$ and $\delta^{15} \mathrm{~N}$ comparison of ossicles and dentine formed around birth show higher values for dentine. The $\delta^{13} \mathrm{C}$ offset between ossicles and peri-natal dentine ranges between 0.5 and 1.4 $\%$ and the $\delta^{15} \mathrm{~N}$ offset of $0.2 \%$.

$\delta^{13} \mathrm{C}$ and $\delta^{15} \mathrm{~N}$ comparison of ossicles and dentine formed by the age of 5 months show higher values for dentine. The only exception is $\delta^{15} \mathrm{~N} \%$ of individual 1615 , with same values for both tissues. The $\delta^{13} \mathrm{C}$ offset between ossicles and dentine formed in the first 5 months after birth ranges between 0.3 and $1.3 \%$ and the $\delta^{15} \mathrm{~N}$ offset between 0.1 and $1.9 \%$. $\delta^{13} \mathrm{C}$ and $\delta^{15} \mathrm{~N}$ comparison of ossicles and dentine formed by the age of 1 year show higher values for dentine. The only exceptions are $\delta^{15} \mathrm{~N}$ of individuals 1615 , with same values of both tissues and 2041 with lower values of dentine. The $\delta^{13} \mathrm{C}$ offset between ossicles and dentine formed by the age of 1 -year ranges from 0.3 to $1.1 \%$ and the $\delta^{15} \mathrm{~N}$ offset from 0.1 to $1.7 \%$.

$\delta^{13} \mathrm{C}$ and $\delta^{15} \mathrm{~N}$ comparison of ossicles and dentine formed by the age of 2 years show higher values for dentine. The exceptions in this case are four, as $\delta^{15} \mathrm{~N} \%$ of individuals 1504,1505 , 1615 and 2041 have higher values observed in the ossicle. The $\delta^{13} \mathrm{C}$ offset between ossicles 
and dentine formed by the age of 2 years ranges from 0.1 to $0.8 \%$ and the $\delta^{15} \mathrm{~N}$ offset from 0.2 to $1.6 \%$.

$\delta^{13} \mathrm{C}$ and $\delta^{15} \mathrm{~N}$ comparison of ossicles and dentine formed after 3 years of age show higher $\delta^{15} \mathrm{~N}$ for ossicles, while $\delta^{13} \mathrm{C}$ values of five individuals $(1504,1615,1625,2081,2137)$ are lower and of five $(2943,1505,2041,2682,2768)$ higher. The $\delta^{13} \mathrm{C}$ offset between ossicles and dentine formed after the age of 3 years ranges from to $0.7 \%$ and the $\delta^{15} \mathrm{~N}$ offset from 0.4 to $2.5 \%$.

Figure 3: Offset between $\delta^{13} \mathrm{C}$ of ossicle and dentine formed at different period of individuals life.

Figure 4: Offset between $\delta^{15} \mathrm{~N}$ of ossicle and dentine formed at different period of individuals life.

\section{Discussion}

Individual dentine profiles (data in Supplementary material) of all 20 children from the Blackburn site included in the study indicate that most were exclusively breastfed until about 6 months and fully weaned before the age of 3 (Figure 5 and Figure 6). This interpretation is mainly based on the $\delta^{13} \mathrm{C}$, which appears to be more robust and reliable for estimating breastfeeding and weaning patterns, as $\delta^{15} \mathrm{~N}$ profiles are more variable, influenced by secondary factors such as physiological stresses experienced by the individuals (Beaumont et al., 2015, 2018). The averaged values for $\delta^{13} \mathrm{C}$ and $\delta^{15} \mathrm{~N}$ in the group $3+\mathrm{y}(-20.0 \%$, $11.4 \%$, respectively) are assumed to represent the post-weaning childhood diet. In the absence of any data from adult bone from this site, we use this value as a proxy for the population diet.

Figure 5: Plot showing incremental dentine collagen $\delta^{15} \mathrm{~N}$ profiles for individuals from Blackburn.

Figure 6: Plot showing incremental dentine collagen $\delta^{13} \mathrm{C}$ profiles for individuals from Blackburn. 
Examination of dentine $\delta^{13} \mathrm{C}$ and $\delta^{15} \mathrm{~N}$ of the age groups represented show high prenatal values $(-19.1 \%$, $13.1 \%$, respectively), that increase in the time around birth $(-18.7 \% 0,13.3$ $\%$, respectively). In the first year after birth $\delta^{15} \mathrm{~N}$ slightly increases $\left(13.5 \%\right.$, while $\delta^{13} \mathrm{C}$ starts to decrease (-19.3\%). Two years after birth both $\delta^{13} \mathrm{C}$ and $\delta^{15} \mathrm{~N}$ show a decrease $(-19.5$ $\%$, $13.0 \%$, respectively) and stabilise between the ages of 2 and 3 years. Peri-natal dentine collagen $\delta^{13} \mathrm{C}$ and $\delta^{15} \mathrm{~N}$ are $1.3 \%$ and $2.9 \%$, respectively, higher when compared to averaged post-weaning childhood values. This is consistent with a trophic level shift and breastfeeding signal model proposed in other research (Fuller et al., 2006, 2003; Haydock et al., 2013). Perinatal dentine collagen $\delta^{13} \mathrm{C}$ and $\delta^{15} \mathrm{~N}$ are slightly higher than prenatal, most likely due to breastfeeding influence on isotopic values after birth (Millard, 2000; Fogel et al., 1989; Fuller et al., 2006). However, the change is quite small and the pre-natal values, which should in fact reflect maternal values during last trimester of pregnancy, relatively high, especially if compared to the same individuals at the age of 3 years (a proxy for the adult diet in this population). This remains the fact even when acknowledging for previously reported $\sim 0.4 \%$ o $\delta^{13} \mathrm{C}$ and $\sim 0.9-1 \% \delta^{15} \mathrm{~N}$ offset between mother and infant pairs (de Luca et al., 2012; Beaumont et al., 2015; Fuller et al., 2006; Beaumont et al., 2013a). Since isotopic studies on hair and fingernails of modern, healthy pregnant women present a slight reduction in $\delta^{15} \mathrm{~N}$ (Fuller et al., 2006, D`Ortenzio et al., 2015), most likely caused by anabolic state induced by pregnancy, the observed increased values are unusual. For a similar situation at Raunds Furnells, Beaumont et al. (2018) offered two possible explanations, either women had different diet during pregnancy - consumption of marine food would elevate both $\delta^{13} \mathrm{C}$ and $\delta^{15} \mathrm{~N}$ (Ambrose et al., 1997; Müldner \& Richards, 2005), or were experiencing physiological and/or nutritional stress, resulting in catabolic state (Fuller et al., 2005; Reitsema, 2013) and enriched $\delta^{15} \mathrm{~N}$, which is normally seen due to insufficient protein ingestion. Elevated $\delta^{13} \mathrm{C}$ could then be explained by the lack of nutrients forcing the body to mobilise fat stored in the 
first two trimesters to be readily available for the foetus in the last trimester (Butte et al., 2000) for energy and tissue synthesis. However, in this research, the size of the studied sample is small and for now no data exists on adult $\delta^{13} \mathrm{C}$ and $\delta^{15} \mathrm{~N}$. Thus, average values for adults from Blackburn and their dietary habits are not established and relation between mother and a child or breastfeeding/weaning interpretation difficult. It is worth mentioning that all but three studied individuals $(1504,1615,1625,2041$ and 2946) do seem to present a normal weaning curve (see Supplementary material) as proposed by previous studies (Millard, 2000; Beaumont et al., 2018). On the other hand, the dentine collagen profile of individual 1615 presents opposite covariance of $\delta^{13} \mathrm{C}$ and $\delta^{15} \mathrm{~N}$ from prenatal period and in first year of life with relatively high $\delta^{15} \mathrm{~N}(11.9-12.3 \%$ ) persisting until death (at the age of approximately 3 years).The profile of individual 2946 indicates higher prenatal $\delta^{15} \mathrm{~N}$ and lower pre-natal $\delta^{13} \mathrm{C}$ in comparison to peri-natal values, $\delta^{15} \mathrm{~N}$ also remaining relatively high $(12.1-12.4 \%)$ until death (at approximately 2 years of age). The profile of individuals 1504 and 2041 show a sudden elevation of $\delta^{15} \mathrm{~N}$ without the corresponding change in $\delta^{13} \mathrm{C}$ around the age of 1.2 years, and the profile of individual 1625 prolonged high $\delta^{15} \mathrm{~N}$. Dentine profiles (Figure 7) of the individuals above thus suggest a secondary factor affecting $\delta^{15} \mathrm{~N}$ values, possibly physiological stress, as already proposed by Beaumont et al. (Beaumont et al., 2018). Individual 2946 might actually show signs of prenatal starvation as enriched $\delta^{15} \mathrm{~N}$ and depleted $\delta^{13} \mathrm{C}$ indicate lack of protein forcing the body to recycle previously stored body fat (Reitsema, 2013; Beaumont \& Montgomery, 2016; Beaumont et al., 2018; Lehn et al., 2015; Cherel et al., 2005).

Figure 7: Ossicle $(\mathrm{O})$ and incremental dentine carbon $(\mathrm{C})$ and nitrogen $(\mathrm{N})$ isotope ratio profiles by estimated age for teeth for individuals 1615, 2041 and 2946 from Blackburn.

Since a detailed interpretation of the dentine profiles is not the aim of this article, further discussion will be omitted for now. Nevertheless, collagen dentine values are increasingly 
accepted as reliable unlike those from infant bone. As such, they are appropriate to form a baseline for comparisons with $\delta^{13} \mathrm{C}$ and $\delta^{15} \mathrm{~N}$ obtained from the ossicles.

The most striking feature in this comparison is lack of any significant correlation between values of ossicles and prenatal values of last trimester (weeks $27-40$ ), peri-natal values, or averaged values up to the 5 months and 1 year of age. Even though values from the ossicles are, to an extent, comparable with averages for dentine formed until the age of 2 , when examined on the individual basis, $\delta^{13} \mathrm{C}$ and $\delta^{15} \mathrm{~N}$ still differ significantly (in most cases more than 1 S.D. $-0.2 \%$ ). This is consistent with their development (see above), as ossicles are almost completely formed at birth, experience only minor changes in the first two years of life and do not remodel afterwards. This interpretation is further confirmed through poorcorrelation of $\delta^{13} \mathrm{C}$ and $\delta^{15} \mathrm{~N}$ dentine formed after the third year of life. At this point the offset seen in $\delta^{15} \mathrm{~N}$ reverses, with ossicles having on average $1.5 \%$ higher $\delta^{15} \mathrm{~N}$ in comparison to dentine, while $\delta^{13} \mathrm{C}$ becomes inconsistent and variable, $0.3 \%$ lower or higher when compared to dentine. .

The lack of correlation between the approximately co-forming ossicle and dentine in the last trimester in utero and in the first year of life is harder to explain than the lack of correlation later in life. One possibility would be an offset between collagen in bone (ossicles) and dentine. Their organic part is composed of predominantly type I collagen, secreted by osteoblast as osteoid matrix and odontoblast as predentin matrix, respectively. However, both are assembled and orchestrated by mesenchymal cells synthesizing collagenous and noncollagenous proteins (Ravindran \& George, 2015) and identifying any systematic distinction between the collagen matrix components of each tissue is difficult (Opsahl Vital et al., 2012; Embery et al., 2001; Huang et al., 2008). As the main differences are seen in non-collagenous proteins and the secondary biomineralization process in the ossicles (Opsahl Vital et al., 2012; Huang et al., 2008), there is no evidence to suggest differences in the collagenous proteins, 
which could support the offset between dentine and bone collagen observed in this and other studies (Beaumont et al., 2018). The offset between the ossicles and the dentine profile in $\delta^{15} \mathrm{~N}$ increases and the offset in $\delta^{13} \mathrm{C}$ decreases from peri-natal values over the time of breastfeeding and beginning of weaning (first year of life), indicating that, on the contrary to dentine, ossicles are probably not significantly influenced by these dietary changes. Even though with only one sample, lack of breastfeeding affecting ossicles can be confirmed with the profile of individual 2164, who died at the age of approximately 6 months thus not surviving through the secondary period of ossicle biomineralization. The $\delta^{13} \mathrm{C}$ and especially $\delta^{15} \mathrm{~N}$ in the ossicles of this individual (-19.2\% and $11.9 \%$ ) are relatively close to the established post-weaning diet (-20.0\%o and $11.4 \%$ ) and significantly lower than dentine perinatal values and values recorded in the first 5 months of life likely affected by breastfeeding ($18.0--18.3 \%$ and $13.1-13.2 \%$ ), with death preventing any influences on ossicles afterwards.

A further hypothesis is that the offset with higher values of $\delta^{13} \mathrm{C}$ and $\delta^{15} \mathrm{~N}$ in dentine when compared to ossicles could also imply nutritional, physiological or emotional stress, recorded in dentine but not in the bone. Beaumont et al. $(2015,2018)$ presented data supporting the hypothesis that stress causes osteoblasts to stop producing bone collagen, while dentinoblasts continue the production of dentine collagen, resulting in the offset between co-forming dentine and bone. Individuals 1615, 2041 and 2946 with indicators of stress in their dentine profiles do present some outstanding variation in comparisons of $\delta^{13} \mathrm{C}$ and $\delta^{15} \mathrm{~N}$ recorded by ossicles and dentine formed in utero and in the first year of life. Ossicles of individuals 1615 and 2041 have higher or the same $\delta^{15} \mathrm{~N}$ as dentine in utero and in the first year of life, but different $\delta^{13} \mathrm{C}$. Individual 2946 shows significantly higher than averaged offset between collagen from ossicles and dentine, most notably in $\delta^{13} \mathrm{C}(0.4-0.5 \%)$. Presumably stressed individuals, including 1504 and 1625, are also among individuals with highest $\delta^{13} \mathrm{C}$ and $\delta^{15} \mathrm{~N}$ 
documented in the ossicles. Nevertheless, a lack of strong correlation with dentine collagen does exclude possibility of ossicles and dentine recording the same variation at the same time. It is impossible to give specific conclusions for these patterns based on such a small sample and the absence of $\delta^{13} \mathrm{C}$ and $\delta^{15} \mathrm{~N}$ data for the adults in the population. However, a plausible explanation would be that $\delta^{13} \mathrm{C}$ and $\delta^{15} \mathrm{~N}$ in ossicles contain information related to the time of pregnancy. This is in accordance with their development, as they start forming at $14^{\text {th }}-16^{\text {th }}$ week and are almost completely formed and ossified by the $32^{\text {nd }}-35^{\text {th }}$ week in utero (Hanson \& Anson, 1962; Whyte et al., 2008; Richard et al., 2017; Lasky \& Williams, 2005). However, low correlation between $\delta^{13} \mathrm{C}$ and $\delta^{15} \mathrm{~N}$ of prenatal (representing the last trimester of pregnancy) dentine collagen and ossicle values also indicate that first two trimesters might explain the isotopic profile of ossicles more that the last trimester in utero.

In theory, one could circle back and understand high $\delta^{15} \mathrm{~N}$ as a proxy for the population diet indicating in utero stress, as $\delta^{13} \mathrm{C}$ offset between ossicles and proxy values is relatively low ( $3 \%$ ). This also agrees with enriched prenatal $\delta^{15} \mathrm{~N}$, well-established as an indicator of stress, with raised prenatal $\delta^{13} \mathrm{C}$ explained by the expected fat storage built up in the first two and utilised in the third trimesters of pregnancy.

\section{Conclusions}

We have shown in this small pilot study that we can obtain $\delta^{13} \mathrm{C}$ and $\delta^{15} \mathrm{~N}$ data from the bone collagen of human ossicles, and that when matched with the incremental dentine profiles of the same individuals, there appears to be a systematic offset between the dentine and ossicle data.

Anatomical studies of ossicle development suggests that there are two phases of mineralization in their development, one in the first 2 trimesters of pregnancy and a second during the 25 months after birth. Our data suggests that the second phase does not include any 
significant turnover in the collagen, thus the collagen data we are obtaining reflects the inutero period.

As this does not appear to match with the third trimester data we are measuring in the incremental dentine profiles, and it appears that the post-weaning isotope values (our proxy for the adult diet) are also offset, the data could provide a biomarker for the diet and physiology of the mother during the first two trimesters of pregnancy. This data is consistent with the need for a woman to be healthy enough to be fertile, and the proposed changes in the isotope ratios as a mother is developing a foetus. In the case of these individuals from Blackburn this suggests slight elevation of the $\delta^{15} \mathrm{~N}$ due to some nutritional stress and a lower value for $\delta^{13} \mathrm{C}$ due to the laying down of fat stores.

Further work is required not only in the assessment of the $\delta^{13} \mathrm{C}$ and $\delta^{15} \mathrm{~N}$ of the matched dentine and ossicles of children from different sites, but also in the perinatal period before the secondary mineralization of the ossicles. It would also be of great value to assess the density of ossicles from infants of different ages using micro-CT in order to narrow down the timing of the secondary mineralization process, and the availability of these from the archaeological record is essential bearing in mind the difficulty of obtaining modern samples.

\section{Disclosure statement}

No financial interest or benefit has arisen from the application of this research.

\section{Funding details}

This work was supported by a Research grant from The Society for the Study of Human Biology. 


\section{References}

AlQahtani S.J., Hector M.P., Liversidge H.M. (2010) Brief communication: The London atlas of human tooth development and eruption. American Journal of Physical Anthropology, 142, 481-490.

Ambrose S.H., Butler B.M., Hanson D.B., Hunter-Anderson R.L., Krueger H.W. (1997) Stable isotopic analysis of human diet in the Marianas Archipelago, Western Pacific. American Journal of Physical Anthropology, 104, 343-361. Available at: https://doi.org/10.1002/(SICI)1096-8644(199711)104:3\%3C343::AID-AJPA5\%3E3.0.CO.

Armour-Chelu M., Andrews P. (1996) Studies of the buried bone from the Overton 1992 excavation, In The Experimental Earthwork Project: 1960-1992, pp. 178-200. Eds M. Bell, F. P.J., and S. W. Hillson. York, UK: Council of British Archaeology.

Ars B. (1989) Organogenesis of the middle ear structures. The Journal of Laryngology \& Otology, 103, 16-21.

Balasse M., Bocherens H., Mariotti A., Ambrose S.H. (2001) Detection of Dietary Changes by Intra-tooth Carbon and Nitrogen Isotopic Analysis: An Experimental Study of Dentine Collagen of Cattle (Bos taurus). Journal of Archaeological Science, 28, 235-245. Available at: http://www.sciencedirect.com/science/article/pii/S0305440399905356.

Beaumont J., Atkins E.-C., Buckberry J., Haydock H., Horne P., Howcroft R., Mackenzie K., Montgomery J. (2018) Comparing apples and oranges: Why infant bone collagen may not reflect dietary intake in the same way as dentine collagen. American Journal of Physical Anthropology, 1-17. Available at: https://doi.org/10.1002/ajpa.23682.

Beaumont J., Geber J., Powers N., Wilson A., Lee-Thorp J., Montgomery J. (2013a) Victims and survivors: Stable isotopes used to identify migrants from the Great Irish Famine to 19th century London. American Journal of Physical Anthropology, 150, 87-98. Available at: http://dx.doi.org/10.1002/ajpa.22179.

Beaumont J., Gledhill A., Lee-Thorp J., Montgomery J. (2013b) CHILDHOOD DIET: A CLOSER EXAMINATION OF THE EVIDENCE FROM DENTAL TISSUES USING STABLE ISOTOPE ANALYSIS OF INCREMENTAL HUMAN DENTINE*. Archaeometry, 55, 277-295. Available at: http://dx.doi.org/10.1111/j.14754754.2012.00682.x.

Beaumont J., Montgomery J. (2016) The Great Irish Famine: Identifying Starvation in the Tissues of Victims Using Stable Isotope Analysis of Bone and Incremental Dentine Collagen. PLOS ONE, 11, e0160065. Available at: https://doi.org/10.1371/journal.pone.0160065.

Beaumont J., Montgomery J., Buckberry J., Jay M. (2015) Infant mortality and isotopic complexity: New approaches to stress, maternal health, and weaning. American Journal of 
Physical Anthropology, 157, 441-457. Available at: http://dx.doi.org/10.1002/ajpa.22736.

Brown T.A., Nelson D.E., Vogel J.S., Southon J.R. (1988) Improved collagen extraction by modified Longin method. Radiocarbon, 30, 171-177.

Burt N.M. (2015) Individual dietary patterns during childhood: an archaeological application of a stable isotope microsampling method for tooth dentin. Journal of Archaeological Science, 53, 277-290. Available at:

http://www.sciencedirect.com/science/article/pii/S0305440314003896.

Burt N.M. (2013) Stable isotope ratio analysis of breastfeeding and weaning practices of children from medieval Fishergate House York, UK. American Journal of Physical Anthropology, 152, 407-416. Available at: http://dx.doi.org/10.1002/ajpa.22370.

Chen H., Okumura T., Emura S., Shoumura S. (2008) Scanning electron microscopic study of the human auditory ossicles. Annals of Anatomy - Anatomischer Anzeiger, 190, 53-58. Available at: http://www.sciencedirect.com/science/article/pii/S0940960207000866.

Cherel Y., Hobson K.A., Bailleul F., Groscolas R. (2005) NUTRITION, PHYSIOLOGY, AND STABLE ISOTOPES: NEW INFORMATION FROM FASTING AND MOLTING PENGUINS. Ecology, 86, 2881-2888. Available at: https://doi.org/10.1890/05-0562.

Collins M.J., Galley P. (1998) Towards an optimal method of archaeological collagen extraction: the influence of pH and grinding. Ancient Biomolecules, 2, 209-222.

Dean M.C., Scandrett A.E. (1995) Rates of dentine mineralization in permanent human teeth. International Journal of Osteoarchaeology, 5, 349-358. Available at: http://dx.doi.org/10.1002/oa.1390050405.

DeWitte S.N., Stojanowski C.M. (2015) The Osteological Paradox 20 Years Later: Past Perspectives, Future Directions. Journal of Archaeological Research, 23, 397-450. Available at: https://doi.org/10.1007/s10814-015-9084-1.

Dornelles C., Schmidt Rosito L.P., Meurer L., da Costa S.S., Argenta A., Alves S.L. (2007) Hystology findings' correlation between the ossicular chain in the transoperative and cholesteatomas. Brazilian Journal of Otorhinolaryngology, 73, 738-743. Available at: http://www.sciencedirect.com/science/article/pii/S1808869415311691.

Duboeuf F., Burt-Pichat B., Farlay D., Suy P., Truy E., Boivin G. (2015) Bone quality and biomechanical function: A lesson from human ossicles. Bone, 73, 105-110. Available at: http://www.sciencedirect.com/science/article/pii/S875632821400461X.

Eerkens J.W., Berget A.G., Bartelink E.J. (2011) Estimating weaning and early childhood diet from serial micro-samples of dentin collagen. Journal of Archaeological Science, 38, 31013111. Available at: http://www.sciencedirect.com/science/article/pii/S0305440311002445.

Embery G., Hall R., Waddington R., Septier D., Goldberg M. (2001) Proteoglycans in 
dentinogenesis. Critical reviews in oral biology and medicine : an official publication of the American Association of Oral Biologists, 12, 331-349.

Feng X., McDonald J.M. (2011) Disorders of bone remodeling. Annual review of pathology, 6, 121-145.

Fogel M.L., Tuross N., Owsley D.W. (1989) Nitrogen isotope tracers of human lactation in modern and archaeological populations. Carnegie Institution of Washington Yearbook, 88, $111-117$.

Fuller B.T., Fuller J.L., Harris D.A., Hedges R.E.M. (2006) Detection of breastfeeding and weaning in modern human infants with carbon and nitrogen stable isotope ratios. American Journal of Physical Anthropology, 129, 279-293. Available at:

http://dx.doi.org/10.1002/ajpa.20249.

Fuller B.T., Richards M.P., Mays S.A. (2003) Stable carbon and nitrogen isotope variations in tooth dentine serial sections from Wharram Percy. Journal of Archaeological Science, 30, 1673-1684. Available at:

http://www.sciencedirect.com/science/article/pii/S0305440303000736.

Hanson J.R., Anson B.J. (1962) Development of the malleus of the human ear. Illustrated in atlas series. Quarterly bulletin. Northwestern University (Evanston, Ill.). Medical School, 36, $119-137$.

Haydock H., Clarke L., Craig-Atkins E., Howcroft R., Buckberry J. (2013) Weaning at Anglo-Saxon raunds: Implications for changing breastfeeding practice in britain over two millennia. American Journal of Physical Anthropology, 151, 604-612. Available at: https://doi.org/10.1002/ajpa.22316.

Hedges R.E.M., Clement J.G., Thomas C.D.L., O’Connell T.C. (2007) Collagen turnover in the adult femoral mid-shaft: Modeled from anthropogenic radiocarbon tracer measurements. American Journal of Physical Anthropology, 133, 808-816. Available at:

http://dx.doi.org/10.1002/ajpa.20598.

Huang B., Sun Y., Maciejewska I., Qin D., Peng T., McIntyre B., Wygant J., Butler W.T., Qin C. (2008) Distribution of SIBLING proteins in the organic and inorganic phases of rat dentin and bone. European journal of oral sciences, 116, 104-112.

King C.L., Millard A.R., Gröcke D.R., Standen V.G., Arriaza B.T., Halcrow S.E. (2017) A comparison of using bulk and incremental isotopic analyses to establish weaning practices in the past. STAR: Science \& Technology of Archaeological Research, 3, 126-134. Available at: https://doi.org/10.1080/20548923.2018.1443548.

van Klinken G.J. (1999) Bone Collagen Quality Indicators for Palaeodietary and Radiocarbon Measurements. Journal of Archaeological Science, 26, 687-695. Available at: http://www.sciencedirect.com/science/article/pii/S0305440398903855. 
Lasky R.E., Williams A.L. (2005) The Development of the Auditory System from Conception to Term. NeoReviews, 6, e141 LP-e152.

Lee-Thorp J.A. (2008) ON ISOTOPES AND OLD BONES. Archaeometry, 50, 925-950.

Lehn C., Rossmann A., Graw M. (2015) Provenancing of unidentified corpses by stable isotope techniques - presentation of case studies. Science \& Justice, 55, 72-88. Available at: http://www.sciencedirect.com/science/article/pii/S135503061400135X.

de Luca A., Boisseau N., Tea I., Louvet I., Robins R.J., Forhan A., Charles M.-A., Hankard R. (2012) [delta]15N and [delta]13C in hair from newborn infants and their mothers: a cohort study. Pediatric Research, 71, 598-604. Available at: http://dx.doi.org/10.1038/pr.2012.3.

Marotti G., Farneti D., Remaggi F., Tartari F. (1998) Morphometric investigation on osteocytes in human auditory ossicles. Annals of Anatomy - Anatomischer Anzeiger, 180, 449-453. Available at: http://www.sciencedirect.com/science/article/pii/S0940960298801064.

Millard A.R. (2000) A model for the effect of weaning on nitrogen isotope ratios in humans, In Perspectives in Amino Acid and Protein Geochemistry, pp. 51-59. Eds G. A. Goodfriend, M. J. Collins, F. M. L., S. A. Macko, and J. F. Wehmiller. New York, USA: Oxford University Press.

Müldner G., Richards M.P. (2005) Fast or feast: reconstructing diet in later medieval England by stable isotope analysis. Journal of Archaeological Science, 32, 39-48. Available at: http://www.sciencedirect.com/science/article/pii/S0305440304001025.

Nanci A. (2008) Ten Cate's Oral Histology: Development, Structure, and Function. Missouri, USA: Mosby Elsevier.

O’Connell T.C., Hedges R.E.M. (1999) Investigations into the effect of diet on modern human hair isotopic values. American Journal of Physical Anthropology, 108, 409-425. Available at: http://dx.doi.org/10.1002/(SICI)1096-8644(199904)108:4\%3C409::AIDAJPA3\%3E3.0.CO.

Opsahl Vital S., Gaucher C., Bardet C., Rowe P.S., George A., Linglart A., Chaussain C. (2012) Tooth dentin defects reflect genetic disorders affecting bone mineralization. Bone, 50, 989-997.

Palumbo C., Cavani F., Sena P., Benincasa M., Ferretti M. (2012) Osteocyte Apoptosis and Absence of Bone Remodeling in Human Auditory Ossicles and Scleral Ossicles of Lower Vertebrates: A Mere Coincidence or Linked Processes? Calcified Tissue International, 90, 211-218. Available at: http://dx.doi.org/10.1007/s00223-012-9569-6.

Paul D., Skrzypek G., Fórizs I. (2007) Normalization of measured stable isotopic compositions to isotope reference scales - a review. Rapid Communications in Mass Spectrometry, 21, 3006-3014. Available at: http://dx.doi.org/10.1002/rcm.3185. 
Ravindran S., George A. (2015) Dentin Matrix Proteins in Bone Tissue Engineering. Advances in experimental medicine and biology, 881, 129-142.

Reitsema L.J. (2013) Beyond diet reconstruction: Stable isotope applications to human physiology, health, and nutrition. American Journal of Human Biology, 25, 445-456. Available at: http://dx.doi.org/10.1002/ajhb.22398.

Richard C., Courbon G., Laroche N., Prades J.M., Vico L., Malaval L. (2017) Inner ear ossification and mineralization kinetics in human embryonic development microtomographic and histomorphological study. Scientific Reports, 7, 4825. Available at: https://doi.org/10.1038/s41598-017-05151-0.

Schoeninger M.J. (2011) Diet Reconstruction and Ecology Using Stable Isotope Ratios, In $A$ Companion to Biological Anthropology, pp. 445-464. Ed C. S. Larse. Chichester, UK: WileyBlackwell.

Schoeninger M.J., DeNiro M.J. (1984) Nitrogen and carbon isotopic composition of bone collagen from marine and terrestrial animals. Geochimica et Cosmochimica Acta, 48, 625639. Available at: http://www.sciencedirect.com/science/article/pii/0016703784900917.

Whyte J., Cisneros A., Yus C., Obon J., Whyte A., Serrano P., Perez-Castejon C., Vera A. (2008) Development of the dynamic structure (force lines) of the middle ear ossicles in human foetuses. Histology and Histopathology, 23, 1049-1060.

Williams P.L., Warwick R., Dyson M., Bannister R.H. (1989) Gray's anatomy 37th ed. Edinburgh; New York.

Wood J.W., Milner G.R., Harpending H.C., Weiss K.M., Cohen M.N., Eisenberg L.E., Hutchinson D.L., Jankauskas R., Cesnys G., Gintautas, x10c, esnys, Katzenberg M.A., Lukacs J.R., McGrath J.W., Roth E.A., Ubelaker D.H., Wilkinson R.G., Česnys G., Wood J.W., Milner G.R., Harpending H.C., Weiss K.M., Cohen M.N., Eisenberg L.E., Hutchinson D.L., Jankauskas R., Cesnys G., Katzenberg M.A., Lukacs J.R., McGrath J.W., Roth E.A., Ubelaker D.H., Wilkinson R.G. (1992) The Osteological Paradox: Problems of Inferring Prehistoric Health from Skeletal Samples. Current Anthropology, 33, 343-370.

Yokoyama T., Iino Y., Kakizaki K., Murakami Y. (1999) Human temporal bone study on the postnatal ossification process of auditory ossicles. The Laryngoscope, 109, 927-930. Available at: http://dx.doi.org/10.1097/00005537-199906000-00016. 
Table 1: Sampled teeth and ossicles from 12 Blackburn individuals.

\begin{tabular}{|c|c|c|c|}
\hline INDIVIDUAL & AGE (years) & SAMPLED TOOTH & SAMPLED OSSICLE \\
\hline 1504 & $6,5 \pm 1$ & permanent upper first molar & malleus \\
\hline 1505 & $6,5 \pm 1$ & permanent upper first molar & incus \\
\hline 1545 & $2 \pm 1$ & deciduous upper first incisor & incus \\
\hline 1625 & $6 \pm 1$ & permanent lower canine & malleus \\
\hline 2041 & $7 \pm 1$ & permanent lower first incisor & malleus \\
\hline 2081 & $13 \pm 1$ & permanent upper second molar & malleus \\
\hline 2137 & $4 \pm 1$ & deciduous upper canine & incus \\
\hline 2164 & $0,5 \pm 0,4$ & deciduous lower first molar & incus \\
\hline 2682 & $12 \pm 1$ & permanent upper second molar & incus \\
\hline 2768 & $10 \pm 1$ & permanent upper first incisor & incus \\
\hline 2943 & $2,5 \pm 1$ & deciduous lower canine & malleus \\
\hline 2946 & $2 \pm 1$ & deciduous lower canine & incus \\
\hline
\end{tabular}


Table 2: Groups established based on dentine formation time.

\begin{tabular}{|c|c|}
\hline GROUP & SECTIONS \\
\hline$P N$ & pre-natal \\
\hline$B$ & peri-natal \\
\hline $5 m$ & average up to 5 months of age \\
\hline $1 y$ & average up to 1 year of age \\
\hline $2 y$ & average up to 2 years of age \\
\hline $3+y$ & average after 3 years of age \\
\hline
\end{tabular}


Table 3: Average $\delta^{13} \mathrm{C}$ and $\delta^{15} \mathrm{~N}$ separately for ossicles $(\mathrm{O})$ and dentine groups.

\begin{tabular}{|c|c|c|c|c|}
\hline \multirow{2}{*}{ GROUP } & \multicolumn{4}{|c|}{ AVERAGE } \\
\cline { 2 - 5 } & $\delta^{13} \mathrm{C}$ \%о (V-PDB) & \pm & $\delta^{15} \mathrm{~N} \%$ (AIR) & \pm \\
\hline $\boldsymbol{O}$ & $\mathbf{- 1 9 . 8}$ & $\mathbf{0 . 4}$ & $\mathbf{1 2 . 8}$ & $\mathbf{0 . 6}$ \\
\hline$P N$ & -19.1 & 0.6 & 13.1 & 0.6 \\
\hline$B$ & -18.7 & 0.5 & 13.3 & 0.4 \\
\hline $5 m$ & -19.1 & 0.6 & 13.5 & 0.5 \\
\hline $1 y$ & -19.3 & 0.5 & 13.5 & 0.7 \\
\hline $2 y$ & -19.5 & 0.5 & 13.0 & 0.8 \\
\hline $3+y$ & -20.0 & 0.3 & 11.4 & 0.7 \\
\hline
\end{tabular}


Table 4: Average $\delta^{13} \mathrm{C}$ and $\delta^{15} \mathrm{~N}$ offset between ossicles and dentine.

\begin{tabular}{|c|c|c|}
\hline \multirow{2}{*}{ GROUP } & \multicolumn{2}{|c|}{ AVERAGE OFFSET } \\
\cline { 2 - 3 } & $\mathrm{d}^{13} \mathrm{C} \%$ (V-PDB) & $\mathrm{d}^{15} \mathrm{~N} \%$ (AIR) \\
\hline$P N$ & -0.6 & -0.4 \\
\hline$B$ & -0.9 & -0.7 \\
\hline $5 m$ & -0.8 & -0.9 \\
\hline $1 y$ & -0.5 & -0.7 \\
\hline $2 y$ & -0.4 & -0.3 \\
\hline $3 y+$ & $-0.3 / 0.3$ & 1.5 \\
\hline
\end{tabular}






Figure 1: Site location, showing planned road alignment and excavation area. 


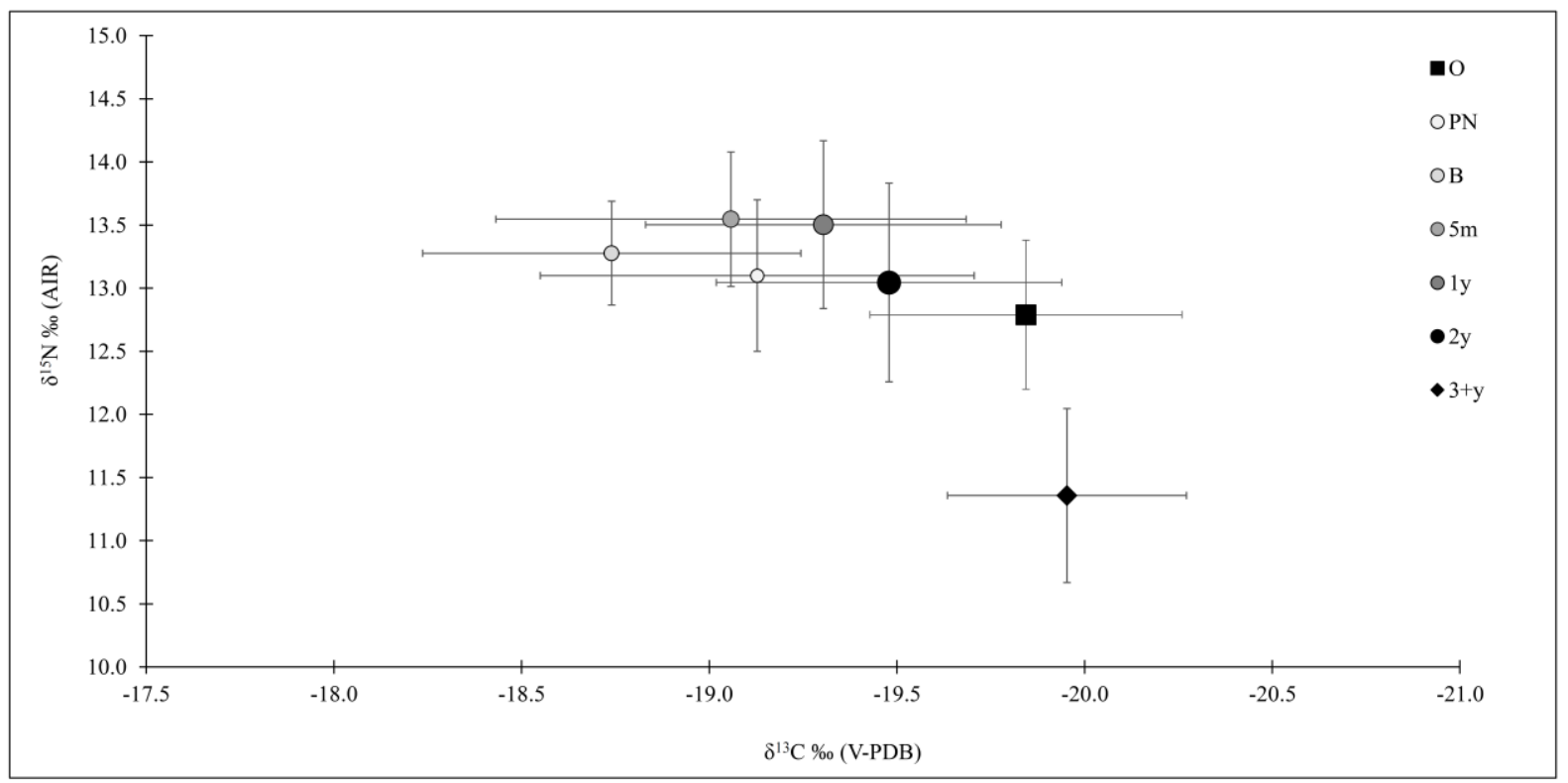

Figure 2: Comparison of $\delta^{13} \mathrm{C}$ and $\delta^{15} \mathrm{~N}$ of ossicles and dentine. 


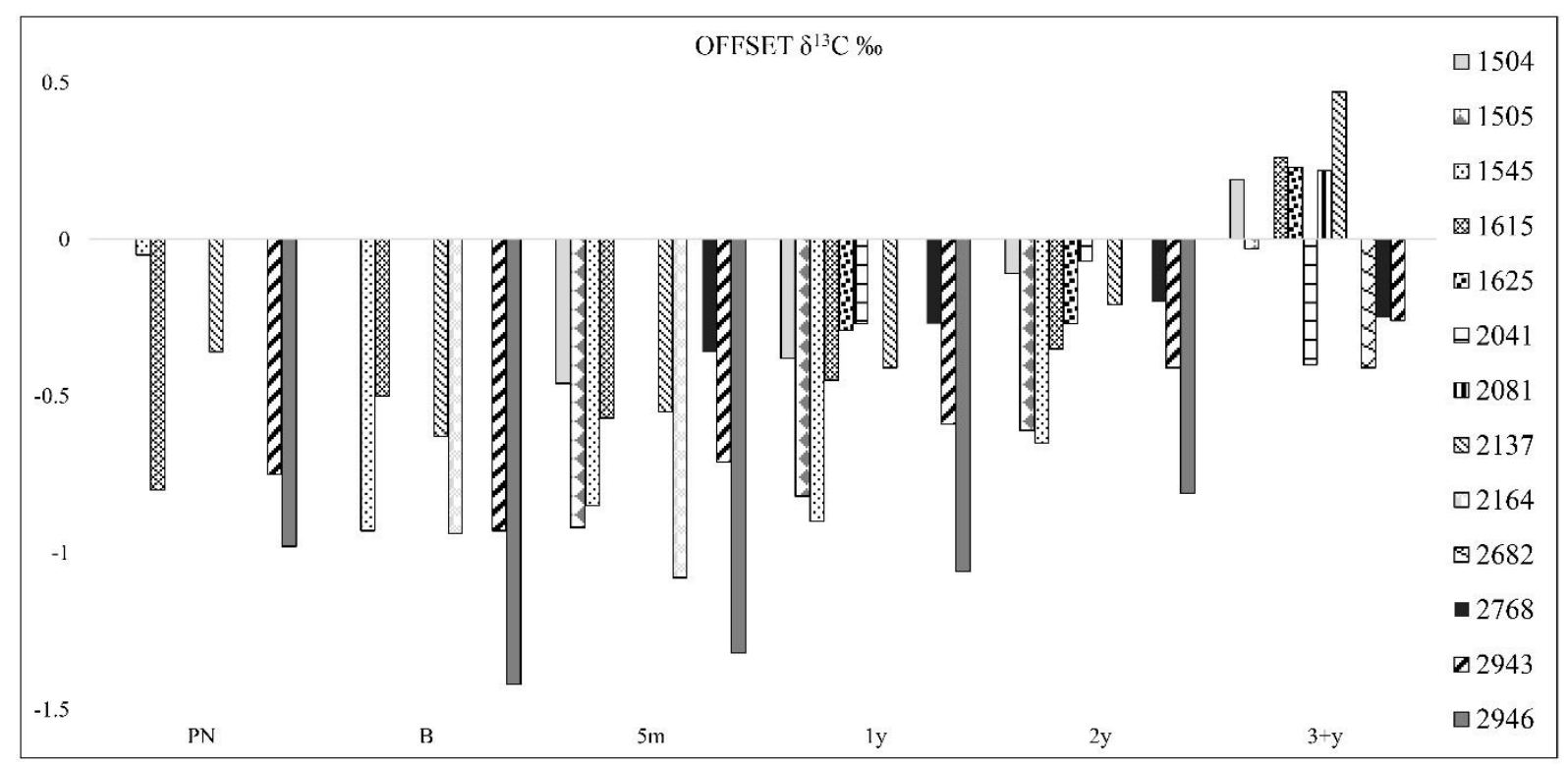

Figure 3: Offset between $\delta^{13} \mathrm{C}$ of ossicle and dentine formed at different period of individuals life. 


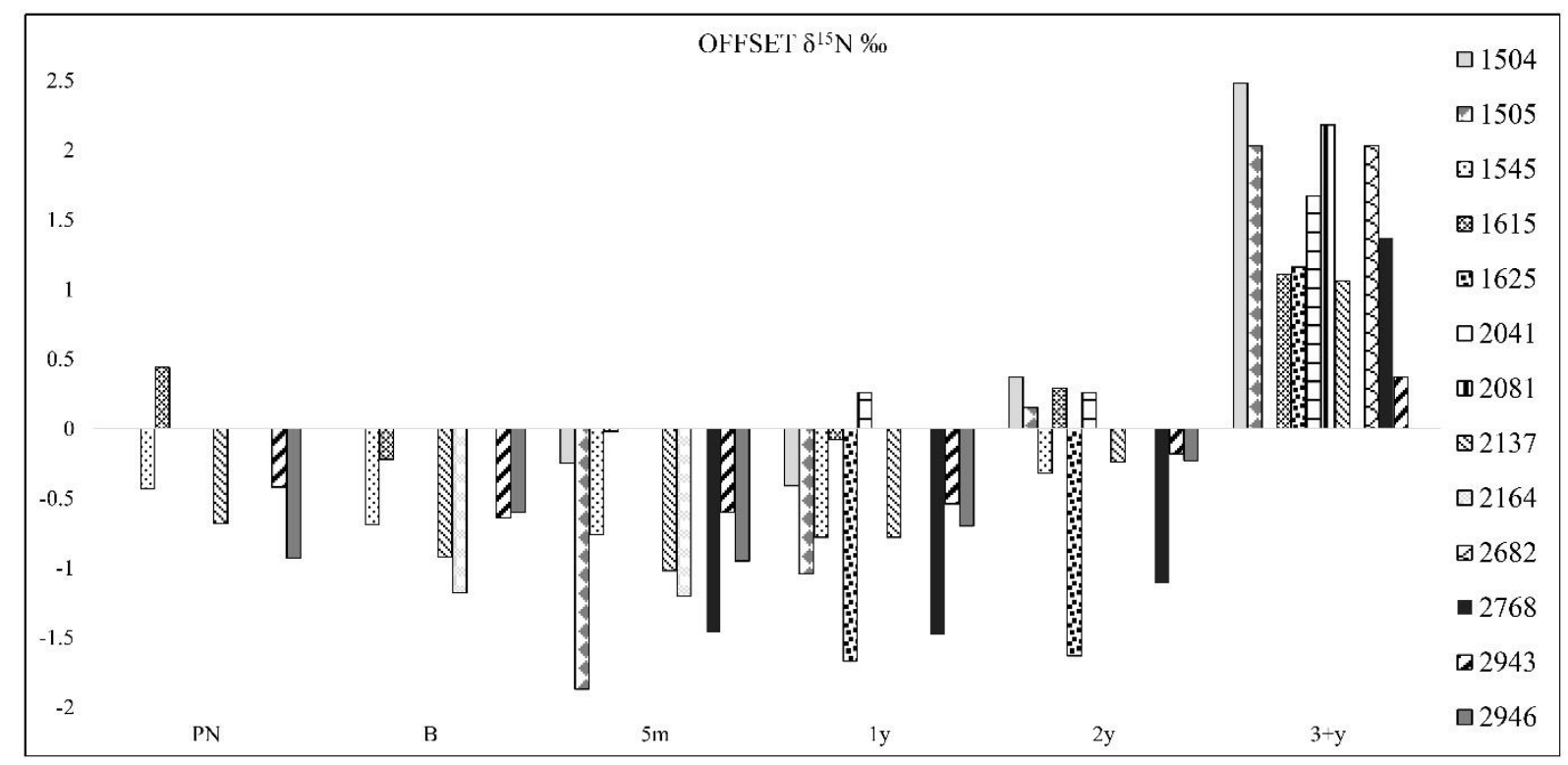

Figure 4: Offset between $\delta^{15} \mathrm{~N}$ of ossicle and dentine formed at different period of individuals life. 




Figure 5: Plot showing incremental dentine collagen $\delta^{15} \mathrm{~N}$ profiles for individuals from Blackburn. 


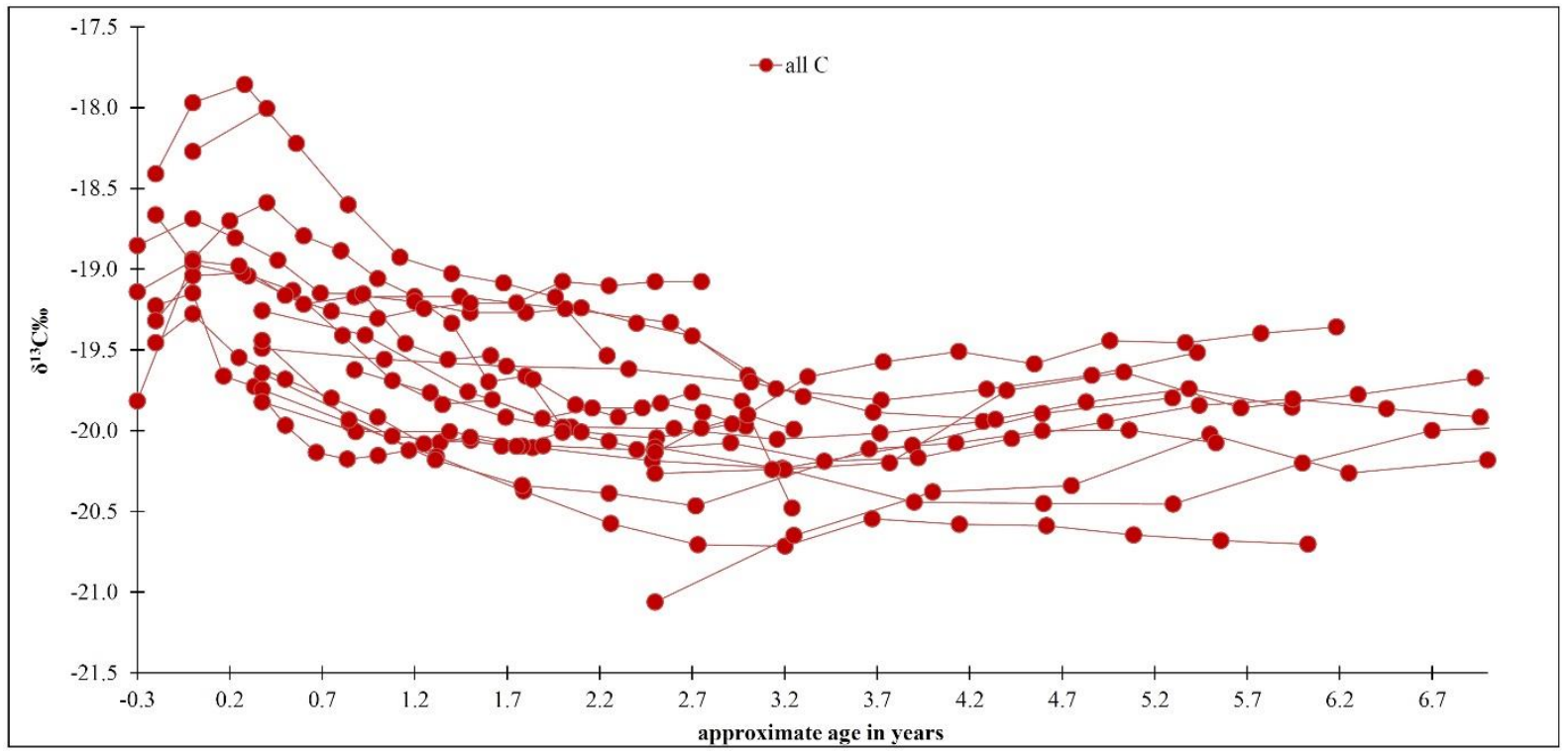

Figure 6: Plot showing incremental dentine collagen $\delta^{13} \mathrm{C}$ profiles for individuals from Blackburn. 


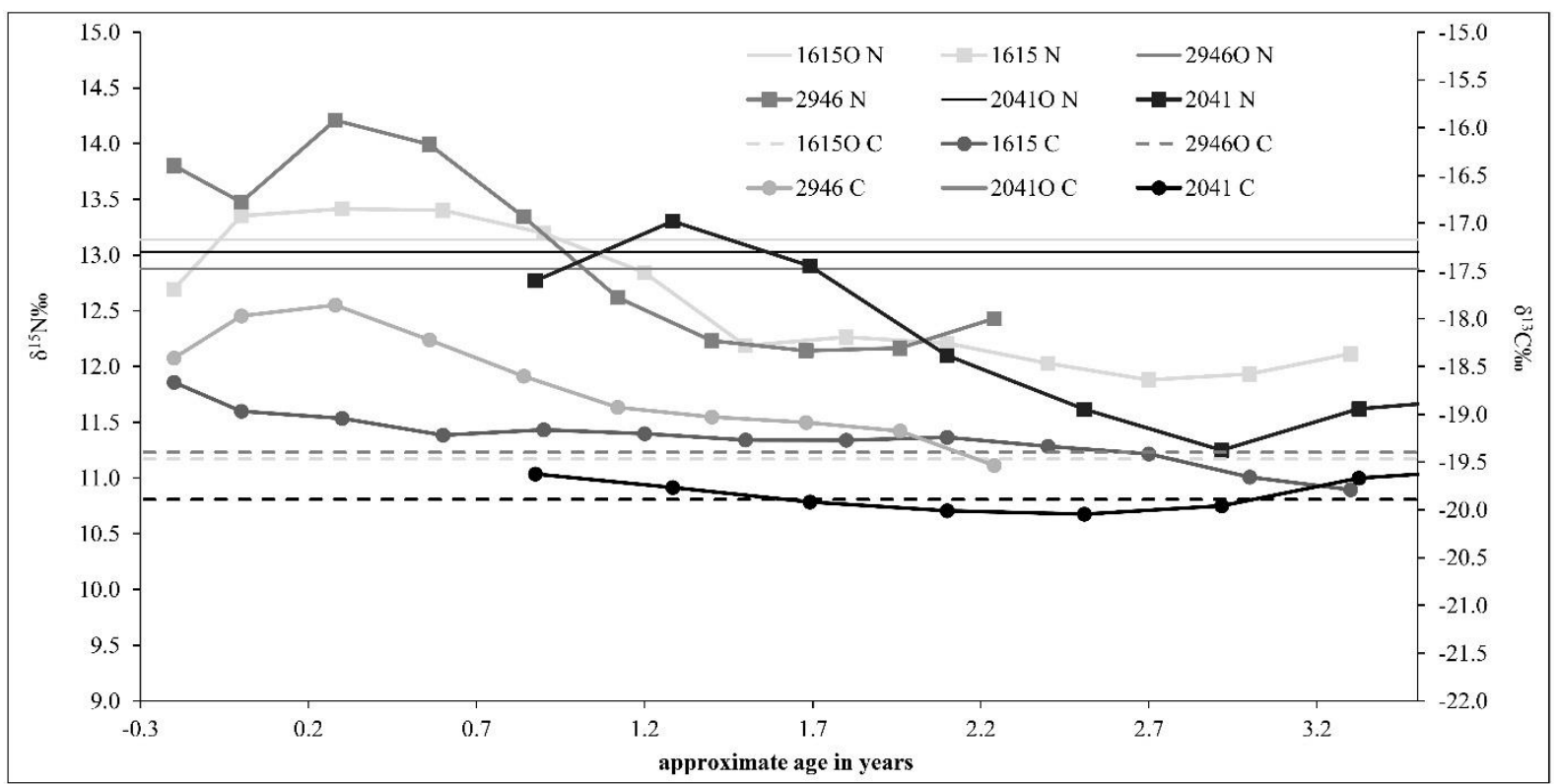

Figure 7: Ossicle (O)and incremental dentine carbon (C) and nitrogen $(\mathrm{N})$ isotope ratio profiles by estimated age for teeth for individuals 1615, 2041 and 2946 from Blackburn. 
Figure 1: Site location, showing planned road alignment and excavation area.

Figure 2: Comparison of $\delta 13 \mathrm{C}$ and $\delta 15 \mathrm{~N}$ of ossicles and dentine.

Figure 3: Offset between $\delta 13 \mathrm{C}$ of ossicle and dentine formed at different period of individuals life.

Figure 4: Offset between $\delta 15 \mathrm{~N}$ of ossicle and dentine formed at different period of individuals life.

Figure 5: Plot showing incremental dentine collagen $\delta 15 \mathrm{~N}$ profiles for individuals from Blackburn.

Figure 6: Plot showing incremental dentine collagen $\delta 13 \mathrm{C}$ profiles for individuals from Blackburn.

Figure 7: Ossicle $(\mathrm{O})$ and incremental dentine carbon $(\mathrm{C})$ and nitrogen $(\mathrm{N})$ isotope ratio profiles by estimated age for teeth for individuals 1615, 2041 and 2946 from Blackburn. 